\title{
Searching for the determinants of OC: Some preliminary reflections
}

\section{Letizia Paoli}

\section{Abstract:}

Given the public concern about organized crime, it is important to identify the determinants of organized crime. Without a better understanding of these determinants, linking them to the different forms of organized crime, policy interventions risk selecting unrealistic goals or even obtaining counterproductive results. It is argued that criminal repression is a necessary reaction to the most serious forms of organized crime, such as a mafia-type organization challenging government authority. Nonetheless, governments should always aim at reducing the total harms associated with organized crime and not lose sight of the fact that they also carry responsibility for these harms.

Letizia Paoli is full professor at the Leuven Institute for Criminology, where she heads the research line 'Organized Crime, Drugs and Terrorism'. Since the 1990s, Paoli has carried out extensive research on different forms of organized crime and illegal markets and their respective control policies, from the Sicilian and Calabrian mafia in Italy to illegal drug markets in Milan, Frankfurt, Russia and worldwide.

E-Mail: Letizia.Paoli@law.kuleuven.be unangemedeft 85.178.18244

Heruntergeladen am | 25.10.13 12:30
Keywords, dt.: Organisiertes Verbrechen, illegale Märkte, Staatlichkeit, Kriminalitätspolitik

Keywords, engl.: Organized crime, illegal markets, statehood, control policies

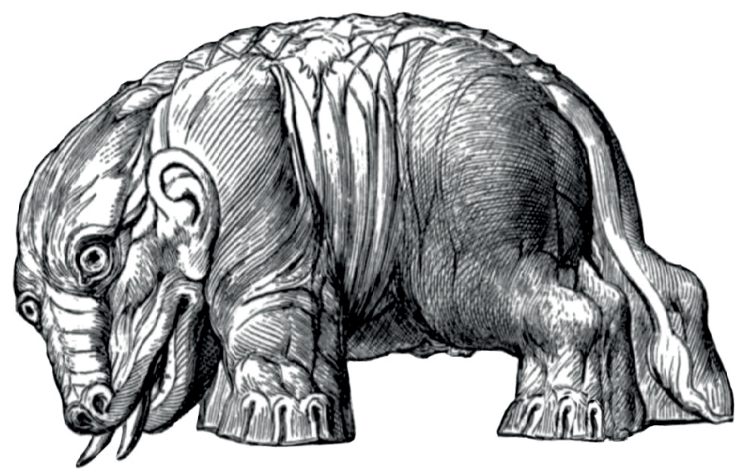


Since the late 1980 s there has been widespread concern about organized crime, even in countries that previously considered themselves unaffected by the problem (e.g., Woodiwiss 2001; Paoli/ Fijnaut 2004). This concern has fed and justified policy reform. To control organized crime, all European states, and several non-European ones as well, have passed far-reaching legal and institutional reforms, and all major international organizations, ranging from the European Union (EU) to the United Nations (UN), have adopted new international treaties and an even larger amount of soft law. The UN Convention on Transnational Organized Crime, which was opened for signature in 2000 and came into force in 2003, represents to date the apotheosis of such international efforts (e.g., Obokata 2010).

Given the public concern about organized crime and the vast array of legal and institutional reforms adopted to control it, it is important to identify the determinants of organized crime. Without a better understanding of these determinants and the causal models linking them to the different forms of organized crime, in fact, policy interventions risk selecting unrealistic goals or even obtaining counterproductive results. Yet this avenue has not been systematically pursued. Even though research on organized crime has greatly expanded over the past 25 years, most studies are descriptive, tend to focus on specific phenomena and/or are often circumscribed to single national or even sub-national contexts, reflecting the difficulties of the empirical data collection. As a result, comparative research has remained very limited (see Fijnaut/Paoli 2004 for an isolate case) and no systematic attention has so far been given to the causes of organized crime (for an overview of recent research, see Paoli 2013).

In this paper, I intend to identify the most relevant promoting factors of organized crime on the basis of the existing literature and my own work. I focus, in particular, on macro-factors or general determinants, which can be defined in accordance with Wikström (2006) as "causes of the causes." I do not consider here situational factors nor do I claim to be exhaustive or even systematic. My contribution is meant to be an invitation to launch a systematic reflection on the crucial issue of the "causes" of organized crime. 


\section{The definitional conundrum}

Looking for an explanans-in our case, the determinants of organized crime-presupposes a clear definition of our explanandum, that is, organized crime itself. Alas, despite its policy relevance, organized crime remains still today an unclear and contested concept. As Mike Levi puts it, organized crime is like the psychiatrist's Rorschach blot, whose "attraction as well as ... weakness is that one can read almost anything into it" $(2002,887)$. Even the official definitions of organized crime are very loose and vague. For example, the 2000 UN Convention on Transnational Organised Crime defines the key concept of "organised criminal group" as a "structured group of three or more persons, existing for a period of time and acting in concert with the aim of committing one or more serious crimes or offences established in accordance with this Convention [i.e., punishable by a maximum deprivation of liberty of at least four years], in order to obtain, directly or indirectly a financial or other material benefit." This means that anything from the Italian Cosa Nostra to a gang of thieves, from Al Qaida to a youth clique or a drug trafficking network can be considered an "organised criminal group" according to the UN text (Paoli 2002b).[1]

De facto, both the scientific and policy discourses have oscillated between two different understandings of organized crime, so much so that it is still unclear if organized crime is to be understood as sets of actors engaging in crime or sets of criminalized activities. At one extreme, organized crime is said to consist of long-lasting criminal organizations with a well-defined collective identity and subdivision of work among its members (Reuter 1983; Paoli 2003)-with protection rackets considered the quintessential function of such organizations (e.g., Schelling 1971; Gambetta 1993). At the other extreme, organized crime is equated to a set of criminalized activities, primarily the provision of prohibited goods and services (e.g., Van Duyne 1997; Edwards/Levi 2008).

Originating from the now discredited alien conspiracy theory, the former view is enthusiastically embraced by the media and the policy-makers seeking to justify draconian measures. Although it is rejected by most scholars, such understanding is corroborated by the existence of a few largescale and long-lasting criminal organizations worldwide, which I have termed elsewhere "mafia-type criminal organizations" (Paoli 2002b). These are primarily the Sicilian Cosa Nostra and Calabrian 'Ndrangheta, the Italian-American La Cosa Nostra, the Chinese Triads, the Japanese Yakuza and the post-Soviet vory v zakone (thieves-in-law or thieves-with-a-code-of-honour).
[1] The recent shift of emphasis from organized to serious crime in the EU policy debate does not help conceptual clarity. In fact, the term "serious crime" is left undefined and merely associated with a list of offences (Dorn 2009). 
The second view, which is now dominant in the scientific understanding of organized crime, is most clearly exemplified by the criminal activities listed as typical of organized crime in the Organized Crime (Threat Assessment) Reports produced at regular intervals by Europol and national law enforcement and governmental agencies (e.g., the UK Serious and Organized Crime Agency and German Bundeskriminalamt). In this second paradigm, depending on the authors and agencies, the identification of organized crime with the provision of illegal goods and services can be complete (e.g., Van Duyne 2007) or merely partial (e.g., Edwards/Levi 2008).[2] Prohibited psychoactive drugs (e.g., heroin, cocaine and cannabis) are the best-known examples of illegal goods but, in addition to them, this category also includes goods produced and traded in violation of specific regulations: human beings, if trafficked for the purposes of sexual exploitation or forced labor; cigarettes, alcohol and gasoline, if exchanged without paying excise and other taxes; diamonds, wood and other natural resources, if extracted illegally or sold outside the legitimate channels. The category of illegal services is also broad, as it ranges from gambling (in those jurisdictions in which it is still prohibited; see Spapens 2013) to paid sex (in jurisdictions where prostitution itself or its exploitation is prohibited) and the entry into a rich country, in the case of human smuggling.

We will use these two ideal-typical views of organized crime as starting points of our analysis.

\section{The determinants of criminal organizations}

A comparative analysis of the major mafia-type criminal organizations indicates that a single general factor played a preponderant role in their rise: the weakness of the local government authorities.

There is a consensus among the scholars who have carried out research on the Southern Italian mafia since the early 1960 s that the origins of the mafia phenomenon in the second half of the nineteenth century-whether it be considered an attitude or an organization-cannot be understood unless the forms and pace of the state-building process in Southern Italy are taken into account. In Charles Tilly's words (1988, xxi), the mafia is "an outgrowth of the particular form that the process of state formation took in Italy." That is to say, the mafia developed because the national system of power expanded without fully subordinating local systems of power. Indeed, it was obliged to actually rely on these systems-constituted by landlords who wanted to maintain their role as feudatory
[2] Organized crime official reports and scholarly studies (e.g., Edwards/Levi 2008) also often include different forms of "illegal transfers" (e.g. robberies, extortions, embezzlement and frauds). Unlike the provision of illegal goods and services, these transfers do not create value but merely transfer it from one person to another. Not least for this very reason, though, the harm they generate is more evident than the harms accruing from the provision of illegal goods and services (see Paoli/Greenfield/Zoutendijk 2013, for an assessment of the harms associated with cocaine trafficking in Belgium). Due to length restrictions, these forms of predatory crimes are not discussed here. 
and mafia organizations-if it wanted to govern at all in the larger areas of Southern Italy. A vicious circle was consequently set in motion, one which has been described very clearly by Henner Hess $(1973,25)$ : "The chronic weakness of the state resulted in the emergence of self-help institutions and the exclusive power positions of informal groups made it impossible for the state to win the loyalty of the public, while its resultant weakness again strengthened the family, the clientele and mafioso positions."

Likewise, The Heaven and Earth Society (Tiandihui), the Chinese "secret society" out of which modern Triads derive, was founded around 1760 in the Fujian province-an area characterized by continuous turmoil, recurrent cycles of rebellion and sustained feuding among the local lineages in the absence of a strong government power (Murray 1994, 6-21). Hui, secret societies, developed in other parts of Southeast China as well, which was then a distant border area and had been unsettled by the transition from the Ming to the Qing dynasty. Founded on fictive blood relationships and distinguishing themselves from other informal institutions through their readiness to use violence, secret societies catered to the needs of marginalized, often young men, whose ranks had increased due to population growth and the increased commercialization fostered by foreign trade (Ownby 1993).

The ancestors of the modern Yakuza groups-that is, the itinerant bands of Japanese roadside gamblers (known as bakuto) and peddlers (tekiya) - are known to have been active since the Middle Ages to provide protection to their members. Long tolerated by Japanese government institutions, Yakuza groups were able to substantially expand their size, economic and political power in two phases in which the Japanese government was particularly weak: the first half of the 19th century and after Japan's defeat in the Second World War (Hill 2003). Founded in Stalinist prisons in the 1930 , vory v zakone and other Russian crime groups have gained unprecedented political power and control over economic resources after the implosion of the Soviet Union in 1991 (Volkov 2013).

State weakness as the key determinant of mafia-type criminal organizations is mirrored in what is regarded as the quintessential function of such organizations: the provision of protection. Gambetta $(1993,1)$ has gone as far as defining the Sicilian mafia as "a specific economic enterprise, an industry that produces, promotes and sells private protection.” While Gambetta's analysis can be criticized for his one-sided emphasis on protection and his denial of the multifunctionality of mafia-type organizations,[3] he must be credited with having rediscovered the political dimension of Southern Italian mafia organizations that had been neglected in the studies conceptualizing mafia groups as
[3] Founded on pre-modern status and fraternization contracts, mafia-type organizations have historically been used by their members to achieve a plurality of goals and to accomplish a variety of functions. As Dian Murray puts it, the members of the first Chinese secret societies "originally organized for one purpose sometimes found themselves mobilized for different ends, and simultaneously involved in activities where the distinctions between 'legal' and 'illegal', 'protection' and 'predation', or 'orthodox' and 'heterodox' blurred" $(1994,2)$. Only by sacrificing empirical evidence it is possible to single out an encompassing function or goal that can characterize mafia-type criminal organizations throughout their lives. 
illicit enterprises (e.g., Catanzaro 1991). Although mafia bonds have been exploited over the decades and centuries for a plurality of different aims, the provision of protection and, more generally, the exercise of political functions remain the typifying activities of mafia-type criminal organizations, so much so that they can be considered as political communities that are not fully institutionalized. These groups act as political bodies toward their own members, but throughout their history they have been struggling-with varying degrees of success-to force their own primordial legal order onto the entire population of their territory and to endow it with legitimacy. They have never succeeded, however, in neutralizing all the rival centers of power (Paoli 2003; see also Hill 2003 and Volkov 2013).

While criminal groups posing as proto-states rose in several parts of pre-modern Europe (e.g., Egmond 2004), most of them were swept away by the consolidation of modern state structures. The current mafia-type organizations have survived in contexts in which government structures have remained weak or a considerable portion of them have been willing to enter into pacts with mafia-type organizations. At least up to the mid-twentieth century, for example, Italian government authorities came to terms with the representatives of mafia power and de facto delegated to the latter the maintenance of public order over wide areas of Western Sicily and Southern Calabria, where the authority of the central government was scarce and even the personal safety of state officials was in danger. As the Parliamentary Anti-Mafia Commission (Commissione 1993) finally acknowledged in 1993 "in practice, the relationships between the institutions and mafia took place, for many years, in the form of relationships between two distinct sovereignties: neither would attack the other, as long as each remained within its own boundaries. [...] The state attacked only when the Cosa Nostra attacked and after that it would go back to the cohabitation."

In Japan as well, Yakuza bosses have held close ties with members of the political establishment and specifically the Liberal Democratic Party (LDP), which came into power in 1955 and remained the party of government for all but three of the subsequent fifty-seven years. Until the end of the 1960 s these ties were, according to Hill (2013) and other scholars he quotes, systemic and were not greatly concealed. In 1952, for example, Yakuza were called upon by senior conservative politicians to protect the Diet building against left-wing protestors trying to prevent the passage of the Subversive Activities Bill. Only since the 1970 s have these ties started to be seen as inappropriate and, whenever they have come to light, they have sometimes led to the premature ends of the careers of 
the involved politicians. This does not mean, however, that they are no longer cultivated. According to an informant quoted by Hill (2013), at least six cabinet ministers in a recent LDP government had Yakuza links.

Exploiting the weakness of the state and, at the same time, their own privileged contacts with corrupt politicians and civil servants, mafia-type criminal organizations have traditionally increased their legitimacy by providing income and other non-material advantages to their associates and a variety of services for the general population, such as civil-service jobs, a pension benefit or impunity for their supporters or votes for befriended politicians. Additionally, in Italy, Japan, Russia and Chinese communities all over the world, they have occasionally controlled the workforce and carried out "dirty work" for colluding companies and landowners-for example, by protecting them from ordinary criminals or by breaking strikes or other forms of protests. Further, mafia-type organizations have supplied goods and services for which there is, despite their official prohibition, a public demand. It is through the latter function that mafia-type organizations become involved in the criminal activities being considered exemplary of the alternative understanding of organized crime-thus, creating a partial overlapping between the two views. Contrary to what is often maintained however, mafia-type organizations are far from controlling illegal markets worldwide and indeed, according to a plurality of independent researchers, their "market share" has in recent years further declined (Paoli 2002a; see also Hill 2003; Volkov 2013; Chin/Liu 2013).

The relevance of political protection for the survival of mafia-type organizations also emerges from the analysis of the cases in which these groups have been weakened or dismantled. In China, Triad groups were swept away by the Communist regime that took over in the 1949 and survived only outside mainland China and specifically in Hong Kong and Macao, where they were tolerated by the local government authorities (Chu 2005). The strengthening of the Russian government structures in the first decades of the twenty-first century and specifically the increased efficiency of Russian courts have also considerably reduced the demand for the protection and mediation provided/ imposed by the local organized crime groups and reduced the latter's control of legitimate markets (Volkov 2013). 


\section{The determinants of criminal activities}

It is almost a platitude to note that public demand constitutes the main determinant for the provision of illegal goods and services. The evidence for such a statement is most compelling in the case of illegal drugs. Considerable research has been carried out on the topic, and many scholars agree that drug production can be eventually pushed by a successful upstream intervention from one location to another but will not be reduced in its global dimension as long as there is not a corresponding decline in demand. The illegal drug industry is like a balloon: when it is "squeezed" or curbed in one location, it tends to "bulge" or re-emerge in another location (e.g., Friesendorf 2007; Paoli, Greenfield/Reuter 2009).

The so-called "balloon effect" applies not only to production but also trafficking. In exceptional circumstances, law enforcement agencies of contemporary democratic governments have been able to stop traffickers from using certain locations for their drug shipments. Such successful interventions, however, have been possible only on islands-particularly the Caribbean-that are easy to control (e.g., 100\% searches on all air passengers boarding at Curacao International Airport in the early 2000s). It has turned out to be impossible to replicate such successes with democratic means in any large country with many border crossings. Moreover, even when they have been successful, as in the case of the Dutch police in Curacao, these interventions have led to the shifts of drug trafficking routes to other countries-the Dutch police's measures in Curacao unintentionally contributed to the emergence of Western Africa as a cocaine transshipment venue (UNODC 2007, 6).

Despite the ultimate powerful role of demand, it would be unjustified to conclude that political conditions have no impact on illegal markets. For example, they play a key role in determining the location of production of opiates (specifically, heroin) and cocaine. In their book on the world heroin market, Paoli et al. (2009) conclude that the location of opium poppy cultivation depends heavily on the role of governments, because after meeting some basic climatic and socio-economic needs, effective illegality-that is, the degree to which the prohibition on opiate production and trafficking are effectively enforced-constitutes a major determining factor. All else being equal, cultivation tends to concentrate in countries with no effective enforcement of opium prohibitions and with local government or quasi-government tolerance or support for opiate production and trade. Afghanistan and Burma, the world's two leading opium producers, most clearly illustrate this principle. Mutatis 
mutandis, the same analysis seems also to fit cocaine. Like opium, coca, the plant that gives rise to cocaine, grows in only a few relatively poor countries, although technically speaking it could grow in many other countries and has historically been grown in Java, Taiwan and Bengal. None of the three major coca growing countries, i.e., Colombia, Peru, and Bolivia, strictly enforces prohibitions on cultivation in growing regions.

The draconian measures occasionally imposed by authoritarian governments and quasi-state authorities also vividly demonstrate the impact that government decisions can have, at least in the short-term, on illegal markets. In less than twelve months from the start of the new century, the Taliban regime in Afghanistan achieved what most scholars and policy makers had thought to be impossible: namely, it cut Afghanistan's illicit opium production by over 90 percent from peak levels, amounting to a 65 percent reduction in world production. The Taliban ban was lifted when the Americans invaded Afghanistan after 9/11; since then opium production in Afghanistan has returned to, and surpassed, previous record-breaking levels (Paoli et al. 2009). Most experts agree that, even if the Taliban had remained in power, the opium ban would have not been sustainable in the long run. The recent experience in Burma, where opium production started to increase again since 2006 after having been squashed by the Wa and other quasi-government authorities in the Shan State seems to confirm that prediction. It also exemplifies the balloon effect, as opium cultivation has largely moved from the areas controlled by the quasi-state authorities to neighboring regions formally administered by the Burmese government (UNODC 2010).

In at least one case, the draconian measures of an authoritarian government have also achieved long-term, lasting change. The radical and concerted opium suppression campaign by the new Communist-led regime in the early 1950 os eliminated opium consumption and production in China, then still by far the largest market in the world. Much like the bans of the Taliban regime and Wa authorities, such a campaign entailed degrees of coercion that no democratic government can rightfully employ (Zhou 2000). Moreover, the coercive measures of the Communist government may not have been the only determinant of the illegal market change. Without downplaying the achievement of the Communists' anti-drug crusade, Dikötter, Laaman and Zhou (2004, 208f.) convincingly argue that medical and social variables were at least as important as the political factors in the long-term decline of narcotic culture. Penicillin began to be sold in the 1940s as the first antibiotic capable of treating a whole range of diseases that had been previously managed with opiates. The social status 
of opium was already on the decline in the 1930s: by then social elites had begun to consider opium smoking morally reprehensible and old-fashioned and started to praise abstinence instead. As in Java (Rush 1985), tobacco smoking progressively superseded opium smoking.

Totalitarian regimes have also been able to prevent the integration of their countries into international illegal markets. Most Western illegal drugs, for example, were unavailable in Russia until the implosion of the Soviet Union in 1991.[4] The bulkier the product is, the higher the chances of control. The Iron Curtain effectively deprived 400 million people of their right of free movement-and "protected" them from falling prey to human trafficking and smuggling.

The chances of controlling illegal markets are, however, much more limited for democratic governments committed to the rule of law and market economy. As long as these are not willing to resort to authoritarian border and law enforcement methods or to disrupt legitimate trade by, say, inspecting every container crossing their national borders, it will be almost impossible for them to stop illegal market flows. Indeed, these can be regarded as the price we need to pay for democracy and market economy. Much like the informal economy, of which they are part, illegal markets constitute a "normal", unavoidable component of all modern state societies (Portes/Castells/Benton 1991, 299). Contemporary governments have even less leverage than their predecessors over illegaland legal-market flows as a result of economic globalization and deregulation. The diminution of state-enforced restrictions on exchanges across borders-the core trait of globalization-has accelerated the interconnections between previously separate domestic legal and illegal markets and increased the mobility of goods, capital and human beings. At the same time, economic liberalization has reduced the ability of governments to withstand and regulate market forces and has unintentionally facilitated the sectors of the global economy that remain criminalized (Andreas 2002). For illegal entrepreneurs it has become easier than ever to move drugs and other illegal commodities from producing to consuming countries, to repatriate profits, to establish business partnerships with foreign counterparts and even to operate in foreign countries themselves.

If the prospects of controlling global illegal market flows are quite bleak, the in-depth analysis of the world heroin market by Paoli et al. (2009) suggest that government authorities, even in democratic societies, are not powerless vis-à-vis organized crime activities. One of their main conclusions is that the strictness of governments' enforcement of prohibitions-in other words, the degree of effective illegality to which opiates (i.e., opium and its derivatives, including heroin) are subject-is
[4] A variety of locally-produced illegal psychoactive drugs were nonetheless consumed (see Paoli 2002a.). 
the most important single factor to shape how the opiate/heroin market is organized in a particular country and the behavior of its producers and traffickers. It impacts, in particular, the size, organization and operating methods of enterprises that produce or traffic illicit opiates.

These findings tie in well with a growing body of literature on organized crime in Western countries that shows that the great majority of illegal exchanges in Western countries are carried out by numerous, relatively small and often ephemeral enterprises. In other words, "disorganized crime" (Reuter 1983), rather than organized crime understood in terms of large-scale stable criminal organizations, predominates on the illegal markets of Western countries, reflecting the constraints deriving from the enforcement of prohibitions. These constraints have to do with the fact that illegal market entrepreneurs are obliged to operate both without and against the state.

First, since the goods and services they provide are prohibited, illegal market actors cannot resort to state institutions to enforce contracts and have violations of contracts prosecuted. Nor does the illegal arena host an alternative sovereign power to which a party may appeal for redress of injury. As a result, property rights are poorly protected, employment contracts cannot be formalized, and the development of large, formally organized, long-lasting companies is strongly discouraged (Reuter 1983).

Second, all illegal market actors are forced to operate under the constant threat of arrest and confiscation of their assets by law enforcement institutions. Participants in criminal trades will thus try to organize their activities in such a way as to assure that the risk of police detection is minimized. Incorporating illegal transactions into kinship and friendship networks and reducing the number of customers and employees are two of the most frequent strategies illegal entrepreneurs employ to reduce their vulnerability to law enforcement moves (ibid.; see also Bouchard/Morselli 2013).

Due to the threat of police intervention, either in terms of seizing assets or imprisoning participants, the planning time horizons of illegal entrepreneurs are likely to be much shorter than those in legal markets. Since an illegal enterprise can hardly be sold as the entrepreneur ages, he is likely to divert an increasing share of his profits to legal assets which can be passed on to his heirs.

Finally, since they are operating against the state, illegal enterprises are prevented from marketing their products. They cannot create their own brand image and try to bind customers to it. Strong economies of scale, however, are associated with advertising and the advantages linked to the nationwide marketing of one's own products have long been recognized as a very important factor 
in the rise of modern large-scale corporations. Illegal enterprises, however, are by definition excluded from the possibility of exploiting these advantages because, by doing so, they would obviously attract law enforcement attention and damage their own businesses. For the same motives illegal enterprises in Western countries resort sparingly to violence: as Pearson and Hobbs $(2001,42)$ put it, "violence and killings attract police attention and leave traces, as well as attracting retaliation. Violence is therefore strictly 'bad for business'."

For all the above reasons, it is rather unlikely that large, hierarchically-organized enterprises will emerge to mediate economic transactions in the illegal marketplace of countries with effective governments. The factors promoting the development of bureaucracies in the legal portion of the economy-namely taking advantage of economies of scale of operations and specialization of rolesare outbalanced in the illegal arena by the very consequences of product illegality. Even mafia-type organizations are subjected to the constraints deriving from the illegal status of products and, when they deal in drugs or other illegal products, they do not operate as monolithic productive and commercial units. On the contrary, their members frequently set up short-term partnerships with other mafia members, or even non-members, to carry out illegal transactions.

Nor are the average illegal market actors of Western countries interested in, or capable of, exercising a quasi-political power similar to that of mafia-type organizations. As Europol $(2003,10)$ recognizes: "politically, few OC groups pose a direct threat to Member States." Most organized crime groups active in the richest Western countries are simply too small and ephemeral to be able to exercise such political power.

The situation can look radically different in countries with lax or no enforcement of official prohibitions. Paoli et al.'s (2009) analysis of the world heroin market, for example, concludes that opiate enterprises can become large and stable and assume bureaucratic characteristics if they are closely linked via corrupt ties to, or coincide with, a powerful state or quasi-state authority. Under conditions of lax or non-enforcement, opiate enterprises may form oligopolies or even monopolies, if powerful and engaged state or quasi-state authorities back them up. The extent of violence and bribery also depends on the strength and involvement of state or quasi-state authorities. Violence may be high, if the supporting state or quasi-state authority is weak; it may be low, if the state or quasi-state authority is strongly institutionalized and directly involved in the drug trade. 
This model also predicts that for countries that have become accustomed to lax or non-enforcement, a shift toward strict enforcement may imply a worsening of drug-related corruption, violence and instability in the interim. What happened in Afghanistan during the first decade of the 21st century clearly demonstrates the potential for worsening conditions: powerful drug producing and trafficking organizations have used all available means to oppose state efforts to enforce prohibition more rigorously and fight for the "right" to continue their established businesses.

Illegality and enforcement seem to have similar effects on the size and operating methods of cocaine and cannabis trafficking enterprises as they have on opiate-related firms. For example, large and stable cocaine trafficking organizations having no qualms about openly challenging state sovereignty have consolidated in countries lacking consistent enforcement of prohibitions, such as Colombia and Mexico (e.g., Thoumi 2012). Presidents Fox and Calderon's determined fight against Mexican drug cartels has plunged the country into an unprecedented spiral of violence. Mutatis mutandis, the model of varying effective illegality seems to be applicable to the enterprises producing and dealing with synthetic drugs and other illegal goods and services.

\section{Concluding remarks}

From a bird's-eye view, the paper has sought to identify the main macro-determinants of the two main forms of organized crime identified in the literature, that is, mafia-type criminal organizations and the provision of illegal goods and services. In doing so, it has shown the limits but also the possibilities of government interventions. The bad news is that democratic governments committed to the rule of law and market economy have limited control over illegal market flows. The good news is two-fold: 1) Mafia-type organizations consolidate only in contexts characterized by a persistent state weakness and can survive only if the government is unable to exercise its core functions and has poor legitimacy or its representatives are willing to come to terms with the mafia groups. 2) Governments can substantially influence the risks assessments and actual behaviors of enterprises that produce or traffic illegal opiates and, possibly, other illegal products. If they can enforce prohibitions with sufficient rigor, they can reduce the violence, corruption and instability associated with illegal markets. The advantages of the strict enforcement of prohibitions, though, must be balanced against the social and financial costs of such enforcement to avoid unnecessarily curbing civil liberties, causing 
unintended harm and further burdening state coffers. In the case of opiates, for example, strict enforcement reduces the harms of opiate production and trafficking within the current drug control regime. After considering the costs and unintended consequences of prohibition itself, though, one might well have to conclude that the total harms of opiate production, trafficking, consumption and policies can be better reduced by alternative policy regimes. The United States is a good case in point: the U.S. war on drugs of the past two decades may have helped keep the U.S. drug market relatively "disorganized," but has failed to reach its main goal of reducing drugs availability and has produced huge social and financial costs: it is enough to say that a considerable proportion of the over 2 million people behind bars and about 5 million more on probation or parole have been convicted for drug offenses (Bureau of Justice Statistics 2012).

In other words, criminal repression is undoubtedly a necessary reaction to the most serious forms of organized crime, such as a mafia-type organization challenging government authority. Nonetheless, governments should always aim at reducing the total harms associated with organized crime and policies and not lose sight of the fact that they also carry responsibility for these harms.

\section{Bibliography}

Andreas, P. (2002) Transnational Crime and Economic Globalization. In: Berdal, M./Serrano, M. (eds.) Transnational Organized Crime and International Security. Business as Usual? Boulder: Lynne Rienner: 37-52.

Bouchard, M./Morselli, C. (2013) Opportunistic Structures of Organized Crime. In: Paoli, L. (ed.), Handbook of Organized Crime. New York: Oxford University Press, forthcoming.

Bureau of Justice Statistics, 2012. Total correctional population. http://bjs.ojp.usdoj.gov/index. cfm?ty=tp\&tid=11 $(23 / 12 / 2012)$

Catanzaro, R. (1991) Il delitto come impresa. Storia sociale della mafia. Milan: Rizzoli.

Chin, K.-L./Liu, M. (2013) Chinese Organized Crime. In: Paoli, L. (ed.) Handbook of Organized Crime. New York: Oxford University Press, forthcoming.

Chu, Y. K. (2005) Hong Kong Triads after 1997. In: Trends in Organized Crime 8: 5-12. 
Commissione Parlamentare d'inchiesta sul fenomeno della mafia e sulle altre associazioni similari (1993) Relazione sui rapporti tra mafia e politica con note integrative, doc. XXIII, no. 2, XI Legislature. Rome: Camera dei Deputati.

Dikötter, F./Laarmann, L./Zhou, X. (2004) Narcotics Culture: A History of Drugs in China. Hong Kong: University of Chicago Press.

Dorn, N. (2009) The End of Organised Crime in the European Union. In: Crime Law and Social Change 51: 283-295.

Edwards, A./Levi, M. (2008) Researching the Organization of Serious Crimes. In: Criminology and Criminal Justice 8: 363-388.

Egmond, F. (2004) Multiple Underworlds in the Dutch Republic of the Seventeenth and

Eighteenth Centuries. In: Fijnaut, C./Paoli, L. (eds.) Organised Crime in Europe: Concepts, Patterns and Policies in the European Union and Beyond. Dordrecht: Springer.

Europol (2003) 2003 European Union Organised Crime Report. Luxembourg: Office for the Official Publications of the European Communities.

Fijnaut, C./Paoli, L. (eds.) (2004) Organised Crime in Europe: Concepts, Patterns and Policies in the European Union and Beyond. Dordrecht: Springer.

Fijnaut, C./Paoli, L. (2009) Transnational Organised Crime. In: Wolfrum, R. (ed.) Max Planck Encyclopedia of Public International Law. Oxford: Oxford University Press, online edition.

Friesendorf, C. (2007) US Foreign Policy and the War on Drugs: Displacing the Cocaine and Heroin Industry. London: Routledge.

Gambetta, D. (1993) The Sicilian Mafia. The Business of Private Protection. Cambridge: Harvard University Press.

Hess, H. (1973) Mafia and Mafiosi: The Structure of Power. Farnborough: Saxon House.

Hill, P. (2003) The Japanese Mafia: Yakuza, Law and the State. Oxford: Oxford University Press.

-----. (2013) Japanese Yakuza. In: Paoli, L. (ed.) Handbook of Organized Crime. New York: Oxford University Press, forthcoming.

Levi, M. (2002) The Organisation of Serious Crimes. In: Maguire, M./Morgan, R./Reiner, R. (eds.) The Oxford Handbook of Criminology, $3^{\text {rd }}$ ed. Oxford: Oxford University Press: 878-913. 
Murray, D., in cooperation with Baoqi, Q. (1994) The Origins of the Tiandihui. The Chinese Triads in Legend and History. Stanford: Stanford University Press.

Obokata, T. (2010) Transnational Organised Crime in International Law. Oxford: Hart.

Ownby, D. (1993) Chinese Hui and Early Modern Social Order: Evidence from Eighteenth Century Southeast China. In: Ownby. D./Somers Heidhues, M. (eds.) Secret Societies Reconsidered: Perspectives on the Social History of Modern South China and Southeast Asia. Armonk: East Gate Book: 34-67.

Paoli, L. (2002a) The Development of an Illegal Market: Drug Consumption and Trade in PostSoviet Russia. In: British Journal of Criminology 42 (1): 21-39.

-----. (2002b) The Implementation of the UN Convention against Transnational Organized Crime: Concepts and Actors. In: Albrecht, H.-J./Fijnaut, C. (eds.) The Containment of Transnational Organized Crime. Comments on the UN Convention of December 2000. Freiburg: Edition iuscrim: 207-233.

-----. (2003) Mafia Brotherhoods. Organized Crime, Italian Style. New York: Oxford University Press.

Paoli, L./Fijnaut, C. (2004) General Introduction. In: Fijnaut, C./Paoli, L. (eds.) Organised Crime in Europe: Concepts, Patterns and Policies in the European Union and Beyond. Dordrecht: Springer: $1-19$.

Paoli, L./Greenfield, V.A./Reuter, P. (2009) The World Heroin Market: Can Supply Be Cut? New York: Oxford University Press.

Paoli, L./Zoutendijk, A./Greenfield, V.A. (2013) The Harm of Cocaine Trafficking: Applying a New Framework for Assessment. Journal of Drug Issues, forthcoming.

Paoli, L. (ed.) (2013) Handbook of Organized Crime. New York: Oxford University Press, forthcoming.

Pearson, G./Hobbes, D. (2001) Middle Market Drug Distribution. London: Home Office.

Portes, A./Castells, M./Benton, L.A. (1991) Conclusions: The Policy Implications of Informality. In: Portes, A./Castells, M./Benton, L. A. (eds.) The Informal Economy. Studies in Advanced and Less Developed Countries. Baltimore: John Hopkins University Press: 298-311.

Reuter, P. (1983) Disorganized Crime: The Economics of the Visible Hand. Cambridge: MIT.

Rush, J. (1985) Opium in Java: A Sinister Friend. In: Journal of Asian Studies 44(3): 549-560. 
Schelling, T. (1971) What Is the Business of Organized Crime? In: American Scholar 40 (autumn): 643-52.

Spapens, T. (2013) Illegal Gambling. In: Paoli, L. (ed.) Handbook of Organized Crime. New York: Oxford University Press, forthcoming.

Tilly, C. (1988) 'Foreword' to A. Blok, The Mafia of a Sicilian Village, 1860-1960: A Study of Violent Peasant Entrepreneurs. New York: Polity.

Thoumi, F.E. (2012) Colombian Organized Crime: From Drug Trafficking to Parastatal Bands and Widespread Corruption. In: Siegel, D./van de Bunt, H. (eds.) Traditional Organized Crime in the Modern World: Responses to Socioeconomic Change. New York: Springer: 131-148.

UNODC (2007) Cocaine trafficking in Western Africa: Situation report. Vienna: Author.

UNODC (2010) South-East Asia Opium Survey 2010. Vienna: Author.

Van Duyne, P. (1997) Organized Crime, Corruption, and Power. In: Crime, Law, and Social Change 26: 201-238.

Volkov, V. (2013) The Rise and Fall of Organized Crime in a Transitional Economy: The Case of Russia. In: Paoli, L. (ed.) Handbook of Organized Crime. New York: Oxford University Press, forthcoming.

Wikström, P.O. (2006) Individuals, Settings and Acts of Crime: Situational Mechanisms and the Explanation of Crime. In: Wikström, P.-O./Sampson, R. (eds.) The Explanation of Crime: Context, Mechanism and Development. Cambridge: Cambridge University Press: 61-107.

Woodiwiss, M. (2001) Organized Crime and American Power. Toronto: University of Toronto Press.

Zhou Y. (2000) Nationalism, Identity and State Building: The Anti Drug Crusade in the People's Republic, 1949-1952. In: Brook, T./Tadashi Wakabayashi, B. (eds.) Opium Regimes: China, Britain and Japan, 1839-1952. Berkeley: University of California Press: 380-404. 